\title{
Hydrogeomorphic processes and torrent control works on a large alluvial fan in the eastern Italian Alps
}

\author{
L. Marchi ${ }^{1}$, M. Cavalli ${ }^{1}$, and V. D'Agostino ${ }^{2}$ \\ ${ }^{1}$ Consiglio Nazionale delle Ricerche - Istituto di Ricerca per la Protezione Idrogeologica (CNR IRPI), Padova, Italy \\ ${ }^{2}$ Dipartimento Territorio e Sistemi Agroforestali, Università di Padova, Legnaro (Padova), Italy
}

Received: 17 November 2009 - Revised: 26 February 2010 - Accepted: 8 March 2010 - Published: 23 March 2010

\begin{abstract}
Alluvial fans are often present at the outlet of small drainage basins in alpine valleys; their formation is due to sediment transport associated with flash floods and debris flows. Alluvial fans are preferred sites for human settlements and are frequently crossed by transport routes. In order to reduce the risk for economic activities located on or near the fan and prevent loss of lives due to floods and debris flows, torrent control works have been extensively carried out on many alpine alluvial fans. Hazard management on alluvial fans in alpine regions is dependent upon reliable procedures to evaluate variations in the frequency and severity of hydrogeomorphic processes and the long-term performance of the torrent training works. An integrated approach to the analysis of hydrogeomorphic processes and their interactions with torrent control works has been applied to a large alluvial fan in the southern Carnic Alps (northeastern Italy). Study methods encompass field observations, interpretation of aerial photographs, analysis of historical documents, and numerical modelling of debris flows. The overall performance of control works implemented in the early decades of 20th century was satisfactory, and a reduction of hazardous events was recognised from features observed in the field and in aerial photographs, as well as from the analysis of historical records. The 2-D simulation of debris flows confirms these findings, indicating that debris flow deposition would not affect urban areas or main roads, even in the case of a high-magnitude event. Present issues in the management of the studied alluvial fan are representative of situations frequently found in the European Alps and deal with the need for maintenance of the control structures and the pressures for land use changes aimed at the economic exploitation of the fan surface.
\end{abstract}

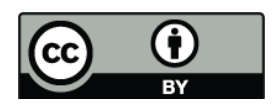

Correspondence to: L. Marchi (lorenzo.marchi@irpi.cnr.it)

\section{Introduction}

Alluvial fans at the outlet of small, high-gradient drainage basins are a common feature of alpine valleys. Although debris flows commonly dominate the formation and development of these alluvial fans, also bedload and hyperconcentrated flows contribute to the transfer of sediment from the drainage basin to the alluvial fan and its distribution on the fan surface. These flow processes result in major risk when they encroach settlements and transport routes, which are often present on the alluvial fans of the European Alps. To cope with flow processes and to reduce their hazard, torrent control works have been built on many alpine alluvial fans. As a consequence, the study of contemporary hydrogeomorphic processes must take into account the interactions between natural phenomena and the control works implemented to reduce the risks on human activities.

Three steps can be highlighted in the hazard assessment on alpine alluvial fans:

- recognition of the type of sediment transport processes;

- reconstruction of the frequency and magnitude of hazardous events;

- runout analysis and mapping of the hazardous areas.

The identification of the type of sediment transport processes occurring on alluvial fans, with particular regard to the basic differentiation between bedload and debris flows, is a preliminary step in hazard assessment. The prevailing flow processes can be assessed through the recognition of morphological and sedimentological evidences (Aulitzky, 1982), or based on morphometric parameters of the drainage basin and the alluvial fan (Jackson et al., 1987; Marchi et al., 1993; Bovis and Jakob, 1999; Wilford et al., 2004; De Scally and Owens, 2004). 
The most common approaches in the reconstruction of the frequency of sedimentary events on alpine alluvial fans have tended to be the application of dendrogeochronological methods and the use of historical archival documentation. The dating of the events through dendrogeochronology is applicable on alluvial fans with forests in relatively natural condition. In the European Alps, this requirement is often met on alluvial fans covered by protection forests in the upper valleys (Strunk, 1992; Baumann and Kaiser, 1999; Stefanini and Ribolini, 2003; Bollschweiler and Stoffel, 2007), whereas farming and urban areas often occupy alluvial fans located at lower elevations along the lower valleys. The reconstruction of the frequency of past events from historical archives is particularly fruitful where human activities are present and there is therefore documentation of the damage caused to buildings and land by floods and debris flows (Guzzetti et al., 1994; Barnikel, 2004; Marchi and Cavalli, 2007). Depending on availability and quality of historical information and topographic data of deposits, also the magnitude of past hydrogeomorphic events can be estimated, thus permitting to establish magnitude-frequency relations (Brochot et al., 2002; Helsen et al., 2002; Stoffel, 2010).

The methods for the zonation of hazard areas on alluvial fans can be subdivided into three classes: historicalgeomorphological (Aulitzky, 1972, 1994), empirical and semi-empirical (Hungr et al., 1987; Ikeya, 1989) and 2-D numerical models (e.g. O'Brien et al., 1993; Liu and Huang, 2006; Rickenmann et al., 2006). Numerical models have a relatively large data requirement: their application necessitates the assessment of debris-flow volumes and peak discharges, a sound choice of rheological parameters, and a detailed representation of the topography of propagation and deposition areas. Valuable characteristics of numerical models are the spatially distributed assessment of important variables, such as flow depth and velocity, and the possibility of considering different scenarios of event magnitude and rheology.

This paper proposes an integrated approach for the analysis of hydrogeomorphic processes on alpine alluvial fans, with particular regard to the assessment of the performance of torrent control works. Sections 2 and 3 describe, respectively, methods and study area; Sects. 4 and 5 describe and discuss the results. Finally, Sect. 6 summarises the main outcomes of the research.

\section{Methods}

Study methods include field observations, interpretation of aerial photographs, collection and analysis of historical documents and numerical modelling of debris-flow propagation and deposition. The analysis of published and unpublished historical documents made it possible to reconstruct the occurrence of past floods and debris flows, and the development of torrent training works. The interpretation of aerial photographs taken from 1954 to 2003 permitted analysis of the evolution of the vegetation and to identify changes in the degree of hydrogeomorphic activity of the alluvial fan. Field observations of deposits and channel network were undertaken with the objective of recognising the flow processes (debris flows, floods with bedload) and to evaluate their activity in the various parts of the alluvial fan.

Numerical modelling of debris-flow propagation and deposition on the alluvial fan was carried out using the FLO-2D model (O'Brien et al., 1993). FLO-2D is a two-dimensional flood routing code able to simulate inundation area of mud flows spreading on a floodplain and/or on a channel network. FLO-2D follows an explicit finite-difference scheme, which distributes a bulked sediment-graph over a Digital Elevation Model (DEM) of selected square cells by means of the Saint-Venant equations. The dynamic equation is applied for each time step to the eight possible flow directions respect to the central cell and it is combined with the continuity equation for unsteady flow. The inflow volume is described by an entering water hydrograph coupled to a time dependent sediment-concentration graph. The model estimates the energy dissipation caused by the mixture motion by means of the rheological model proposed by O'Brien et al. (1993). This model is also known as quadratic model, because the total shear stress results by adding to the classic Bingham model the product of a constant by the quadratic shear rate. The choice of FLO-2D was suggested by the satisfactory applications carried out in the Italian Alps under different lithological conditions and for various debris-flow typologies (D'Agostino and Tecca, 2006; Sosio et al., 2006). Model application was intended to assess the deposition zones for a debris flow of high magnitude. It provided a further test, alongside the historical approach, based on records of past events and aerial photo interpretation, of the effectiveness of torrent training works.

\section{Study area}

\subsection{Drainage basin and alluvial fan}

The Rivoli Bianchi ("White Rills") alluvial fan is a complex system of coalescing alluvial fans in the Southern Carnic Alps (northeastern Italy) (Fig. 1). The alluvial fan covers an area of $2.71 \mathrm{~km}^{2}$, ranges in elevation from 285 to $570 \mathrm{~m}$ and has a mean slope of $6.6^{\circ}$. Alluvial fan slope displays a marked variability, ranging from $10^{\circ}-11^{\circ}$ at the proximal part to $2^{\circ}-3^{\circ}$ in the lower areas in the northern and southwestern zones.

Six small drainage basins, covering a total area of $6.03 \mathrm{~km}^{2}$, contributed to build the Rivoli Bianchi alluvial fan (Fig. 1). These basins are drained by ephemeral streams, on which sediment transport only occurs during intense runoff events. One stream, the Rio Citate, was responsible for building the majority of the alluvial fan. The Rio Citate drains a basin of $1.02 \mathrm{~km}^{2}$, with a range in elevation from 570 to $1825 \mathrm{~m}$ and an average slope of $49^{\circ}$. 


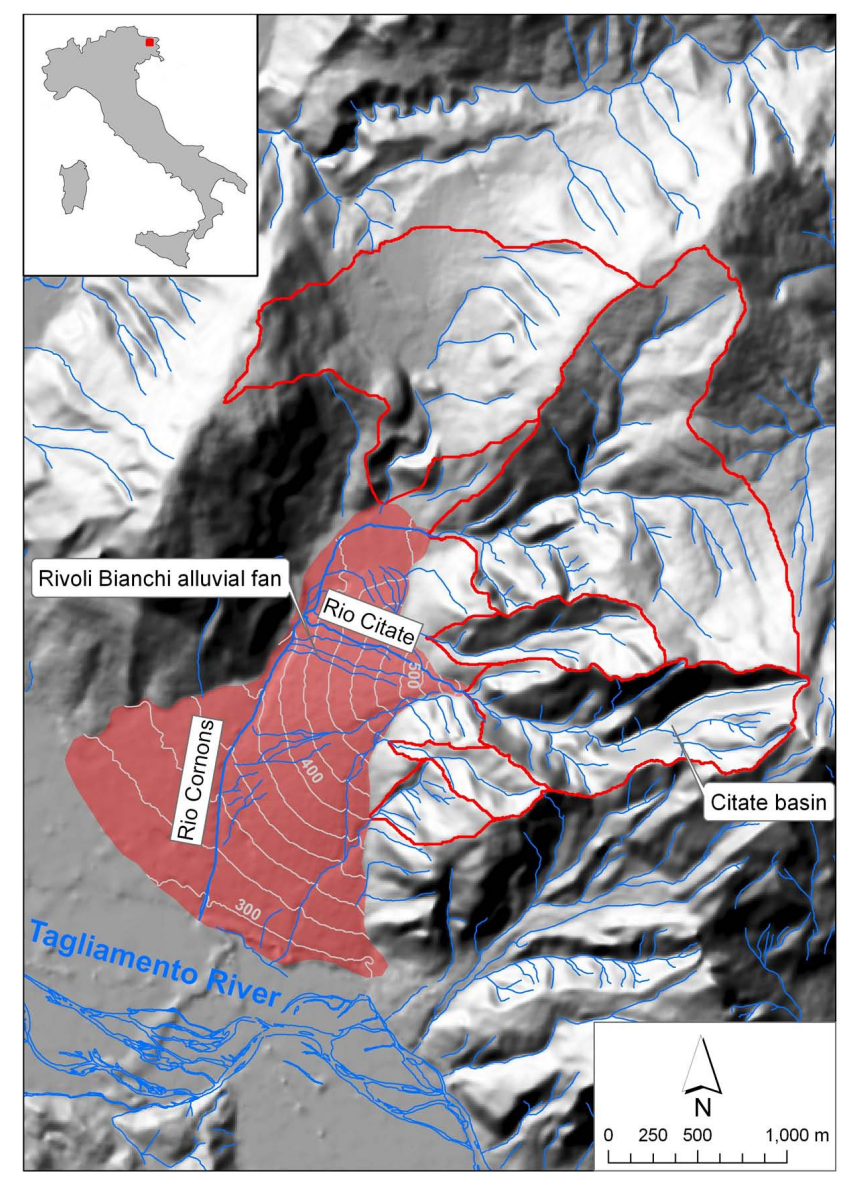

Fig. 1. Topographic map of the Rivoli Bianchi alluvial fan and upslope drainage basins.

Solid bedrock in the study area consists of carbonate rocks (dolomite and limestone); scree slopes are common at the foot of the rock slopes; the distal part of the alluvial fan merges into the alluvial deposits of the main river (Tagliamento River) (Fig. 2).

The study area is located in a seismically active region (Boschi et al., 2000; Carulli and Slejko, 2005). On 27 March 1928, an earthquake with a maximum intensity IX of the Mercalli-Cancani-Sieberg scale, and whose epicentre was approximately $6 \mathrm{~km}$ southwest of the study area (Boschi et al., 2000), caused a large rockfall in the basin of the Rio Citate (Gortani, 1928). The most recent strong earthquake occurred in 1976: a shock of 6.4 magnitude on 6 May was followed by a long seismic sequence with three further strong shocks on 11 and 15 September (magnitude from 5.8 to 6.1 ). The epicentres of the 1976 earthquakes were at a distance of approximately 10 to $15 \mathrm{~km}$ from the study area. Widespread landslides (mostly rockfall) triggered by the 1976 earthquakes were described and mapped by Govi and Sorzana (1977) and Govi (1977). The map of Govi and Sorzana (1977) shows that the seismic shocks of 1976

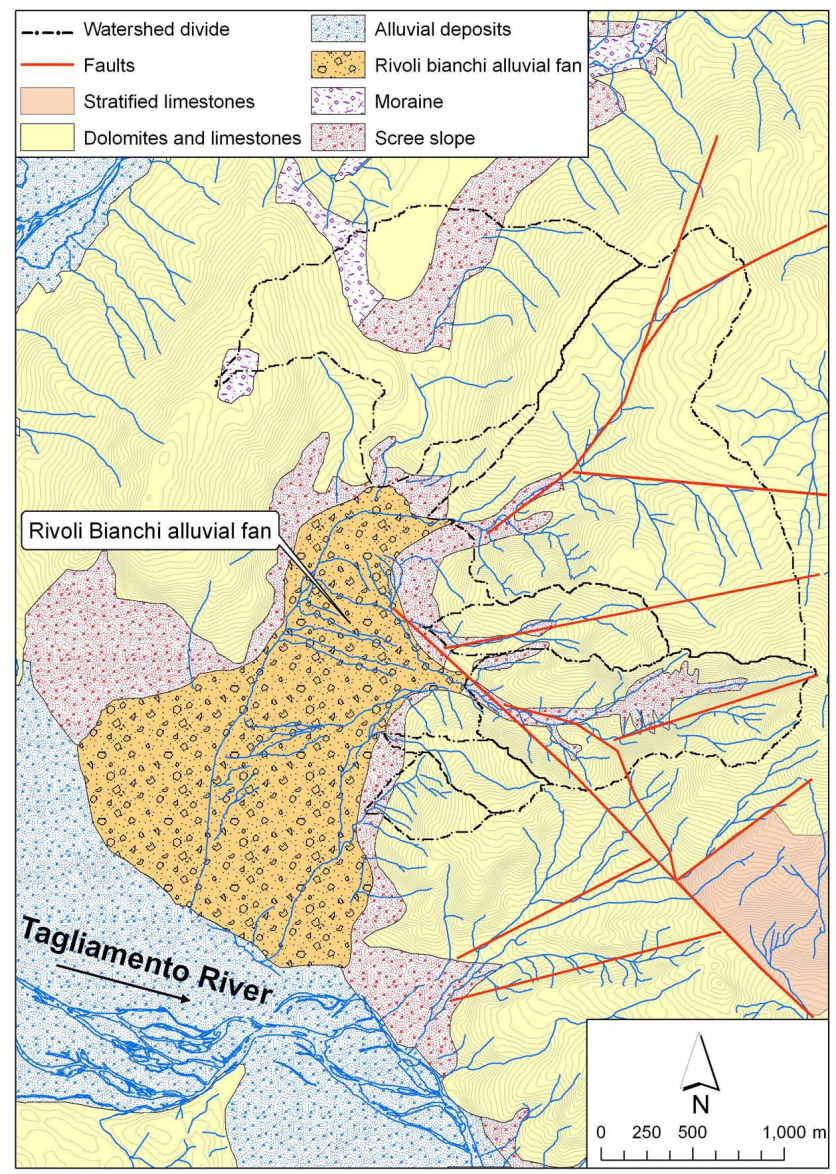

Fig. 2. Geological settings of the study area.

caused the falling of rock blocks in the drainage basin of the Rio Citate. No quantitative data are available on the volumes of debris supplied by the earthquakes to the channel network. However, the sources cited above outline that in the time span of concern in this study, which covers the last 100 years, at least two earthquakes caused rock instability in the feeder basin of the Rivoli Bianchi alluvial fan, thus increasing the availability of mobilisable debris. The assessment of the role of neotectonics on the long-term evolution of the Rivoli Bianchi alluvial fan is beyond the scope and aims of this paper.

Figure 3 shows the relationship between alluvial fan area and basin area for a sample of 62 alluvial fans in the eastern Italian Alps. The wide scatter in the relationship is due to the heterogeneous geolithological and geomorphological conditions in this region. The Rivoli Bianchi alluvial fan lies in the upper part of the scatterplot, regardless if the entire alluvial fan or only the section of it formed by the Rio Citate is considered. The large alluvial fan area is due to abundant sediment supply from the drainage basins, which in turn is caused by steep slopes, active seismicity and a high degree of rock fracturation. 


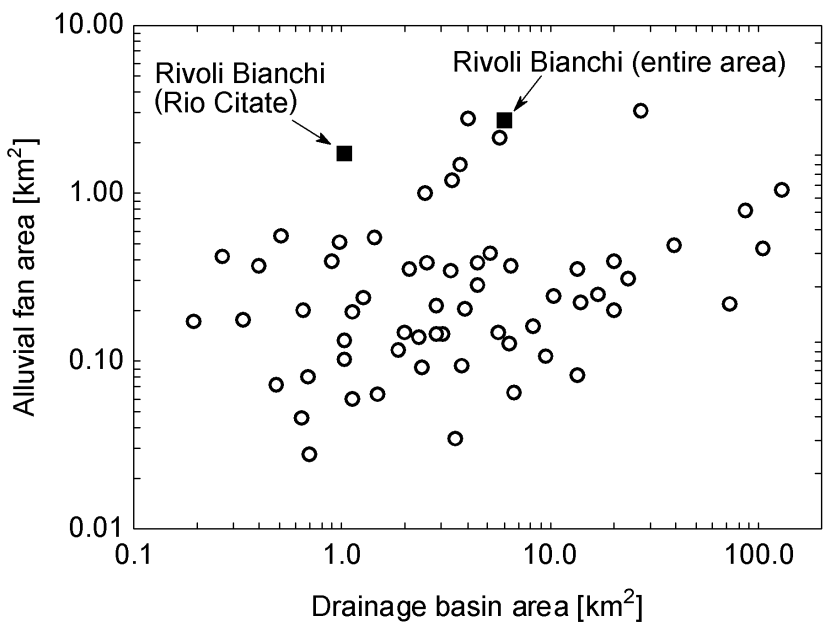

Fig. 3. Relationship between fan area and basin area in the eastern Italian Alps.

Climatic conditions are typical of the easternmost part of the Italian Alps, with abundant precipitation throughout the year: mean annual precipitation amounts to $2000 \mathrm{~mm}$ with maximum in November (approximately $250 \mathrm{~mm}$ ) and minima in January and February (approximately $115 \mathrm{~mm}$ ); the average temperature of the warmest and the coldest months, is $20.1^{\circ} \mathrm{C}$ (July) and $0.6^{\circ} \mathrm{C}$ (January), respectively.

\subsection{Torrent control structures}

Risk to agricultural areas and transport routes, induced by floods and debris flows in the lower part of the alluvial fan, has led to the implementation of works aimed at controlling sedimentary processes.

Early works, constructed in the 19th century, consisted of the construction of an embankment at the western limit of the alluvial fan of the Rio Citate along the confluence with the Rio Cornons. In the early 20th century, an attempt was made to channelise the flow in the southern sector of the fan. A debris flow that occurred in November 1904 (Gortani, 1906) caused major damage to these works, showing their inadequacy.

More systematic hydraulic works were built in the 1920s1930s (Bonicelli, 1928), with repairs and additions made in the following years and decades (Stefanini, 1982). Stone masonry grade-control dams were built within the drainage basin of the Rio Citate and at the fan apex, with the objective of stabilising the channel through the reduction of slope (Fig. 4a). A diversion dike was built on the left bank of the Rio Citate starting from the fan apex, with a length of about $300 \mathrm{~m}$ (Fig. 4b). This structure was intended to direct the flow to the right part of the alluvial fan, preventing flooding of the left (southern) sector, where at-risk elements (national road, railway) were located. More check dams were

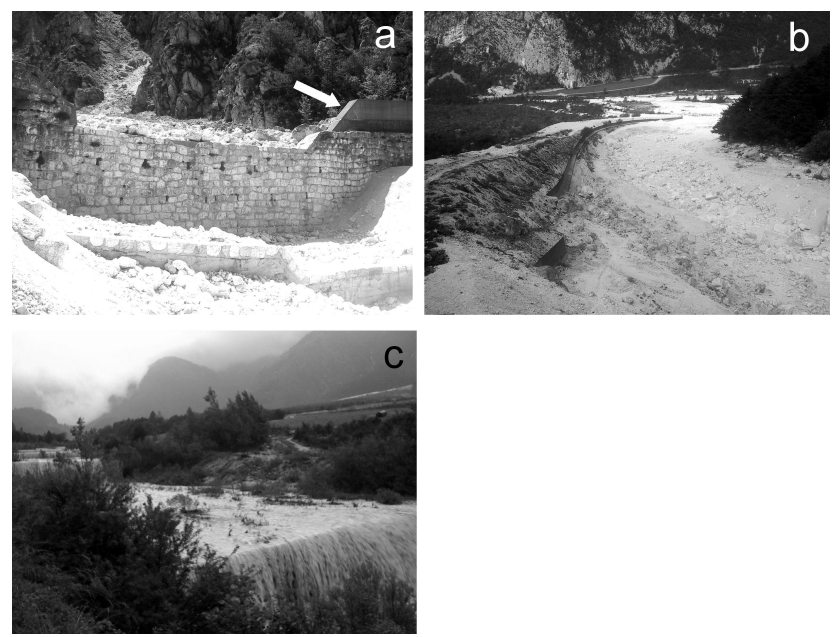

Fig. 4. Torrent control structures. (a) Check dam on the Rio Citate close to the fan apex; the wings of the dam (arrow) were raised in 1985; (b) Deflection dike (built in 1930s and raised in 1985), (c) check dams on the Rio Cornons in the recession phase of a flood (photo by Simona Scarsini).

constructed in the lower part of the left sector and on the Rio Cornons, which borders the alluvial fan of the Rio Citate (Fig. 4c).

\section{Results}

\subsection{Hydrogeomorphic processes}

The hydrogeomorphic processes affecting the Rivoli Bianchi alluvial fan and their evolution in the last century were analysed by means of historical documents, aerial photos and field surveys.

Scientific papers and documents from historical archives (technical reports, newspaper articles, and written communications from local authorities to governmental offices) made it possible to reconstruct the occurrence of the most intense alluvial events on the fan, and provided descriptions of the phenomenology.

Table 1 presents the record of main hydrogeomorphic events on the Rivoli Bianchi alluvial fan since the second half of the 19th century. Documents reporting on floods and debris flows regard major events, which have resulted in damage to properties and transportation routes. Minor events have not been found in the available documentation, therefore meaning that the actual frequency of hydrogeomorphic processes on the Rivoli Bianchi alluvial fan is likely higher than that arising from Table 1 . The most common damage regards the embankment at the western limit of the alluvial fan; whereas damage to embankments and check dams reported after the 1933 and 1935 events indicate that the control constructions were already providing some degree of torrent bed stabilisation. Since the 1970s, thanks to the increased attention of natural hazards and better conservation 
Table 1. Main hydrogeomorphic events on the Rivoli Bianchi alluvial fan.

\begin{tabular}{|c|c|}
\hline Date & Damage \\
\hline 7 Oct 1857 & Damage to the embankment at the western limit of the alluvial fan. \\
\hline 1 Oct 1893 & Damage to the embankment at the western limit of the alluvial fan, flooding of cultivated areas. \\
\hline 23-24 Nov 1904 & $\begin{array}{l}\text { Widespread flooding of the alluvial fan with deposition of large boulders on the upper part. } \\
\text { Damage to the embankment at the western limit of the alluvial fan, } \\
\text { sediment deposition on cultivated areas, sediment obstruction of bridges. }\end{array}$ \\
\hline 20-21 Sep 1920 & Damage to the embankment at the western limit of the alluvial fan. \\
\hline 9 Oct 1933 & Damage to the embankment at the western limit of the alluvial fan. Damage to check dams. \\
\hline 16 May 1935 & $\begin{array}{l}\text { Damage to the embankment at the western limit of the alluvial fan. Damage to check dams. } \\
\text { Bridges on the National Road and railway clogged by sediment. }\end{array}$ \\
\hline
\end{tabular}

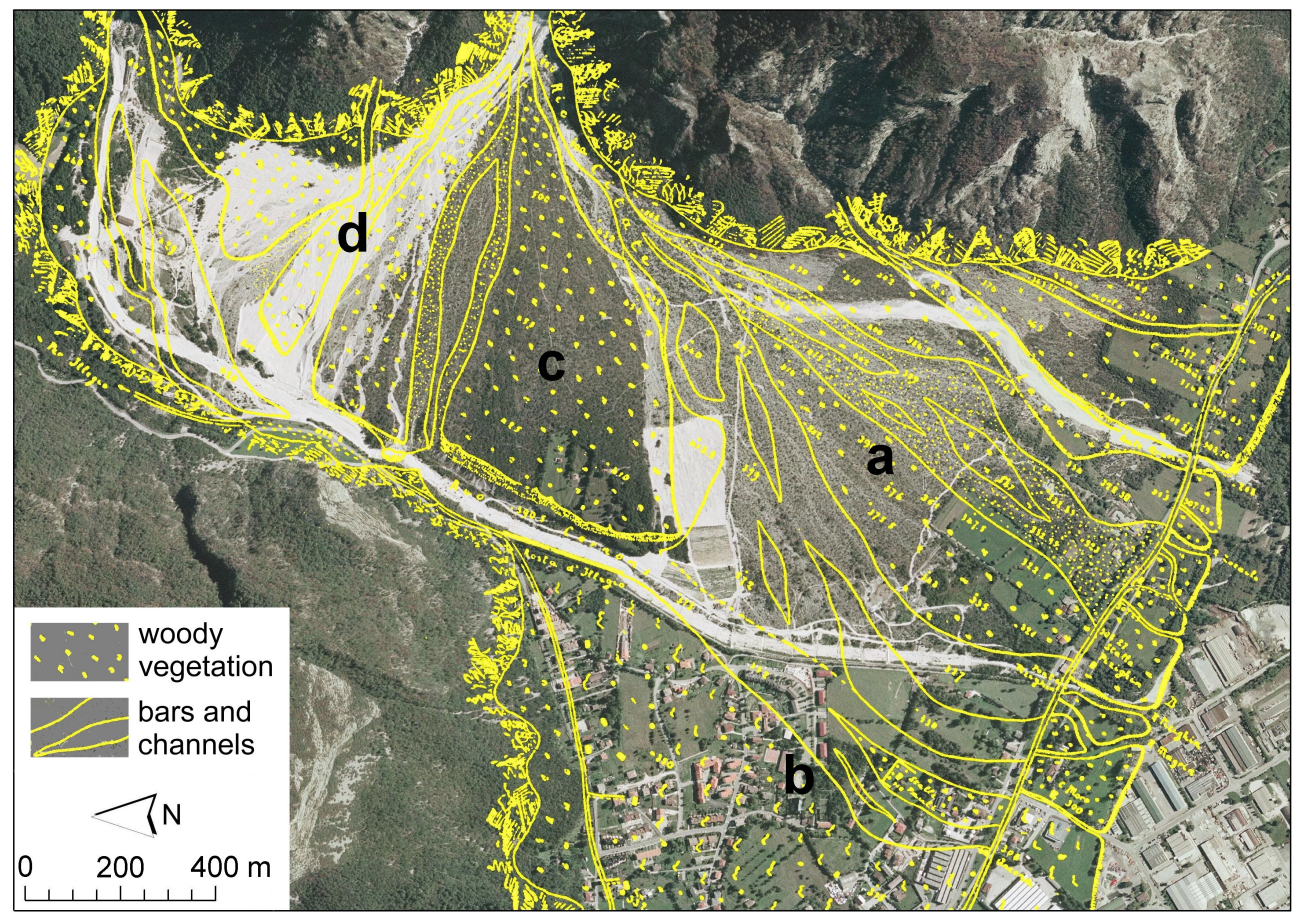

Fig. 5. Historical map of the Rivoli Bianchi fan (Gortani, 1912) overlapped onto an orthophoto taken in 2003. (a) Area characterised by active hydrogeomorphic processes and major hazard before the implementation of training works. (b) Urban expansion. (c) Central sector of the fan, already partly vegetated in the early years of 20th century. (d) The northern part of the fan, formerly less active, serves now as debris deposition area.

of documents, some information is also available for minor events, which did not cause damage to properties and transport routes (e.g. Querini, 1986).

Old documents and papers, when viewed from the modern perspective, usually contain imprecise terminologies for the classification of sedimentary processes. However, the description of phenomena often provides elements useful for the recognition of flow processes. As an example, Bonicelli (1928) provided an effective description of sediment transport on the alluvial fan of Rivoli Bianchi, which outlines typical features of debris flows:

"... the phenomenon of mass transport of gravel along the channels occurs, even if the presence of water flowing on surface appears very limited".

A paper by Gortani (1912) presented a topographic map on the scale of 1:15000 of the Rivoli Bianchi alluvial fan. This map was georeferenced and overlapped onto an orthophoto taken in 2003 (Fig. 5). The comparison of these two pictures makes it possible to evaluate the main changes that occurred in almost 100 years on the alluvial fan. In the Gortani's 

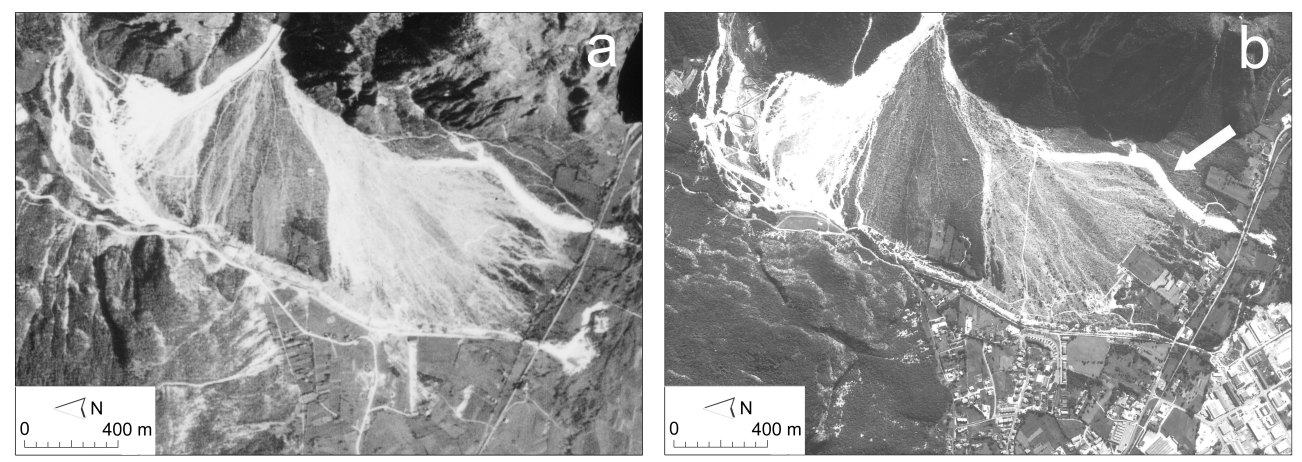

Fig. 6. Aerial photographs of the Rivoli Bianchi alluvial fan taken in 1954 (a) and 1993 (b). The arrow indicates a channel that is still active in the distal part of the fan.

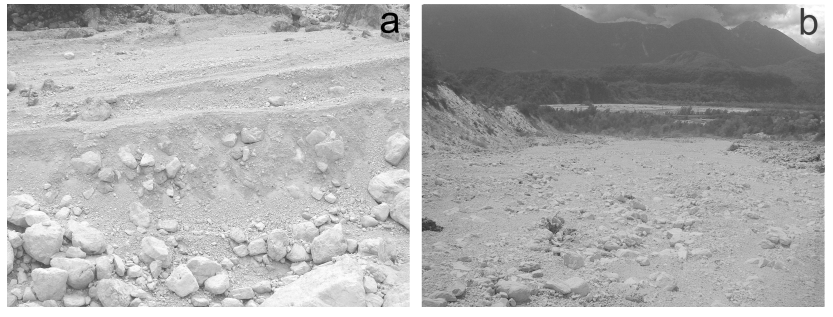

Fig. 7. (a) Clast to matrix supported debris-flow deposits close to the apex of the alluvial fan. The recession stage of the event caused erosion of the deposits, with the formation of different terraces.

(b) Bedload deposits in the distal part of the alluvial fan.

map (1912), the most active areas were in the southern and southwestern parts of the fan, which were crossed by multiple channels. This area is now more stable, and the flow confined to narrow and well-defined channels. It is also worth noting the urban expansion in the southwestern sector of the fan, formerly used for agriculture and partially occupied by active channels (b in Fig. 5). Relatively minor changes have occurred in the central part of the fan, which was already partly vegetated in the early years of 20th century (c in Fig. 5). The northern part of the fan (d in Fig. 5) now serves as a debris storage area.

Aerial photographs make it possible to focus on changes in fan surface that occurred since the 1950s. Figure 6 presents two photographs of the fan, taken in 1954 and in 1993. In 1954, torrent training works had already moved the Rio Citate towards the northern sector of the fan. The most apparent change between 1954 and 1993 is the development of woody vegetation in the southern sector of the fan; where only sparse woody vegetation formerly existed. Woody vegetation on the Rivoli Bianchi alluvial fan mostly consists of open stands of Mountain pine (Pinus montana) and Austrian Pine (Pinus nigra); some trees and shrubs close to old channels show evidence of burial by sediment. The development of vegetation indicates the relative stability of the fan surface. This notwithstanding, a channel is still active in the southernmost part of the alluvial fan, indicated by an arrow in Fig. 6b. The presence of this channel in the lower part of the fan is due to the inflows from two tributaries located south of the Rio Citate basin (Fig. 1), and probably also to saturation overland flow caused by the rise of groundwater after long-lasting rainfall. Sediment transport processes in this channel occurs as bedload, and can involve particles up to the size of pebbles.

Field observation allowed identification of sediment transport and deposition processes currently active on the alluvial fan. Sediment transfer from the drainage basin to the alluvial fan occurs both as debris flows and water floods with bedload and suspended load. Deposits ascribed to debris flows are observed in the upper part of the alluvial fan (Fig. 7a), whereas the distal parts are mostly affected by bedload and suspended load transport (Fig. 7b). Debris-flow deposits consist of angular to subangular, clast to matrix-supported gravel and pebbles with scattered boulders; the debris-flow matrix is composed of granules and coarse to silty sand. Overall, these features of debris-flow deposits are consistent with those generated from other catchments with dolomite rocks (Moscariello et al., 2002).

Historical documents and papers permit reconstructing the occurrence of major hydrogeomorphic events on the Rivoli Bianchi alluvial fan, but do not provide data on their magnitude. However, the Gortani's map (Fig. 5) offers elements for an approximate estimation of areas and sediment volumes involved in the large hydrogeomorphic events that occurred at the end of 19th century and in the first decades of 20th century. The active sectors of the alluvial fan, which correspond to unvegetated areas on the Gortani's map, cover $0.76 \mathrm{~km}^{2}$. Active areas, occupied by fresh deposits and active channels, include both debris-flow deposits and bedload channels and deposits: the occurrence of different flow processes makes it difficult the estimate of sediment volumes. Moreover, the Gortani's map (1912) does not refer to one specific event: it is likely that one event does not affect all active areas. We focus on the debris flows of the Rio Citate, which are the most hazardous processes on the Rivoli Bianchi alluvial fan. 

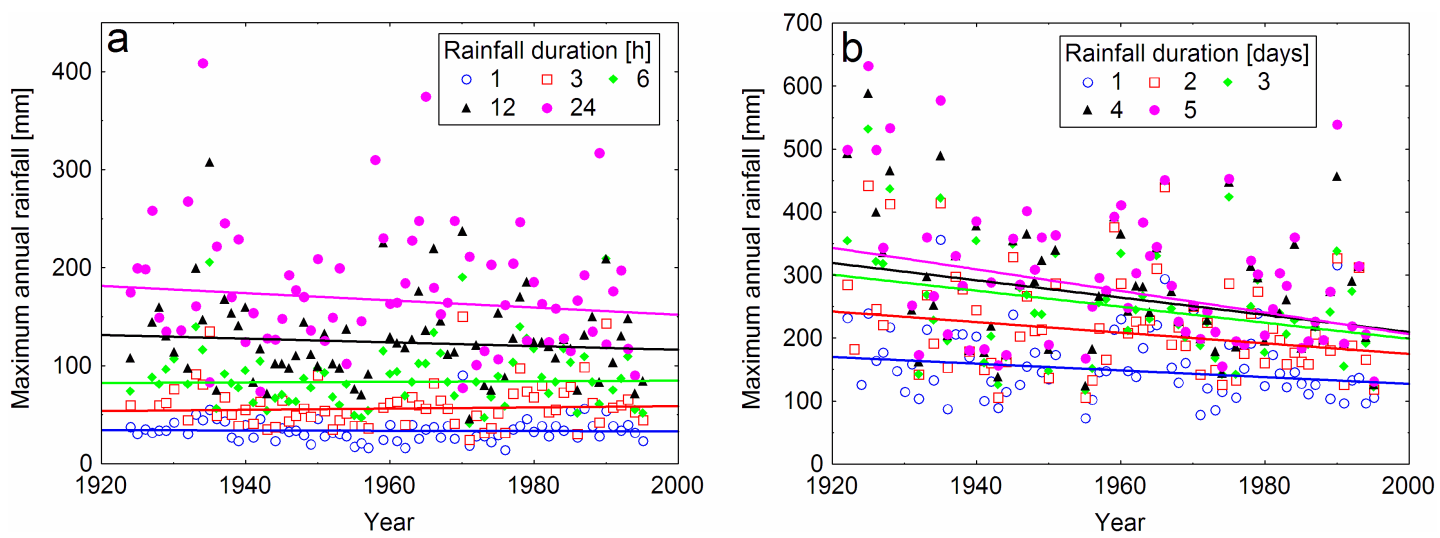

Fig. 8. Maximum annual rainfall and linear trends for durations from 1 to $24 \mathrm{~h}$ (a) and from 1 to 5 days (b). Rainfall was recorded at a raingauge located approximately $3 \mathrm{~km}$ from the study area.

Observations of the deposits on the fan surface indicate that the debris-flows deposits of the Rio Citate are present in the central part of the alluvial fan, corresponding to an area of approximately $0.125 \mathrm{~km}^{2}$ on the Gortani's map. Assuming a mean thickness of the deposits of $1.0 \mathrm{~m}$, we obtain a debrisflow volume of $125000 \mathrm{~m}^{3}$. This value of debris-flow magnitude is affected by approximations in mapping and in the estimation of the thickness of the deposits and should be considered as a roughly approximate estimate.

Trends in the time series of intense precipitation have been investigated through the analysis of maximum annual rainfall of durations of $1,3,6,12,24 \mathrm{~h}$ and 1 to 5 days, recorded from 1922 to 1995 at a nearby raingauge. Figure 8 presents the values of maximum annual precipitation and the Sen's linear model for the trend (Sen, 1968; Salmi et al., 2002). The application of the Mann-Kendall test (Hipel and McLeod, 1994) has shown no trend in the time series concerned for most of the durations. However, at a level of significance of 0.05 , a decreasing trend has been observed for the longest rainfall durations ( 3,4 and 5 days).

\subsection{Debris-flow modelling}

The FLO-2D model was applied to assess the area flooded by a high-magnitude debris flow of the Rio Citate on the Rivoli Bianchi alluvial fan. The simulation was intended to test the performance of control structures in containing debris-flow expansion for a high-magnitude event. Although both debris flows and floods with bedload occur on the Rivoli Bianchi alluvial fan, numerical simulation focuses on a debris flow because debris flows are the main process of sediment transfer from the drainage basin to the alluvial fan and display a higher hazard than bedload.

Debris flows in the Rio Citate originate from erosion and entrainment of loose debris from channel bed and banks and shallow failures of the side slopes. This initiation process and the large availability of mobilisable debris in the catchment make it possible to assess debris-flow discharge from water flood according to the volumetric method proposed by Takahashi (1978). The sediment concentration by volume $\left(C_{\mathrm{v}}\right)$ was supposed linearly increasing and decreasing during the rising and falling stage of the hydrograph respectively, and to reach its maximum value at the flood peak (D'Agostino and Marchi, 2003). It is important to note that the volumetric method is not mass conservative, as it implies that a water discharge is generated by the failure of the saturated stream bed and then is added to the triggering discharge during debris-flow formation (D'Agostino, 2006). The FLO-2D model evaluates the bulked (total water plus sediment) flow rate (Costa, 1984) by means of Eq. (1):

$Q_{\mathrm{d}}=Q_{0} /\left(1-C_{\mathrm{v}}\right)$

where $Q_{\mathrm{d}}$ is debris-flow bulked discharge and $Q_{0}$ is water discharge. Therefore, when setting up the numerical simulation, it was decided to scale up the hydrologic flood hydrograph by adding the water discharge released from channelbed failure. This procedure allowed not to underestimate the maximum $Q_{\mathrm{d}}$ and to save the physical meaning of the sediment concentration (maximum $C_{\mathrm{v}}$ value has been set to 0.70 ; Table 2).

The rainfall-runoff analysis for the computation of the flood hydrograph required by the FLO-2D model was done by means of a distributed kinematic hydrological model based on the USDA-SCS method (Chow et al., 1988). The flood was generated by a hyetograph with 100 years return period, computed from the maximum annual data recorded at a raingauge approximately $3 \mathrm{~km}$ from the Rio Citate basin. The rainfall scenario lasts for $45 \mathrm{~min}$ with increasing intensity. Table 2 summarises the main characteristics of the simulated event.

The method adopted for the assessment of debris-flow volume and hydrograph in the Rio Citate has the advantage of combining geomorphological observations, related to 
Table 2. Summary parameters of hydrological simulation and assessment of debris-flow event in the Rio Citate.

\begin{tabular}{lc}
\hline Rainfall duration (return period of 100 years) $[\mathrm{h}]$ & 0.75 \\
Cumulated rainfall $[\mathrm{mm}]$ & 64 \\
Direct runoff $[\mathrm{mm}]$ & 29 \\
Volume of the hydrologic water hydrograph $\left[\mathrm{m}^{3}\right]$ & 29700 \\
Hydrologic water discharge at the peak $\left[\mathrm{m}^{3} / \mathrm{s}\right]$ & 12.3 \\
Minimum - maximum sediment concentration by volume $[-]$ & $0.12-0.70$ \\
Bulked and scaled up water plus sediment volume $\left[\mathrm{m}^{3}\right]$ & 96000 \\
Debris-flow peak discharge $\left[\mathrm{m}^{3} / \mathrm{s}\right]$ & 123.0 \\
\hline
\end{tabular}

the recognition of erodible volumes, with the hydrological assessment of water runoff, i.e. the agent of debris erosion and entrainment. However, since the assessment of debrisflow magnitude is affected by relevant uncertainties, a consistency check with historical data recorded in the same region is advisable. Figure 9 compares the debris-flow volume estimated in the Rio Citate with a sample of 125 debris flows that occurred in northeastern Italy since late 19th century (Marchi and D'Agostino, 2004). The debris-flow volume computed for the Rio Citate lies in the upper part of the scatterplot of debris-flow volumes versus basin area. This ensures that the debris flow devised for FLO-2D simulation represents a challenging event for evaluating the performance of control structures. The estimated debris-flow volume, although somewhat smaller, has the same order of magnitude of the volume computed on the Gortani's map (Sect. 4.1). The large volume of the debris flow is consistent with the characteristics of the catchment, which is characterised by large availability of erodible debris and steep slopes.

The alluvial fan DEM ( $10 \mathrm{~m}$ grid size) was derived by interpolating elevation data extracted from the topographic maps of the Friuli Venezia Giulia Region (scale 1:5000; contour lines equidistance equal to $5 \mathrm{~m}$ ). The DEM of the alluvial fan, including in it the depressions of the incised channels, represented the FLO-2D domain of computation. The FLO-2D levee component was used to describe more accurately the longitudinal pattern and the top height of the diversion dike on the left bank of the Rio Citate (Fig. 4b). The hydraulic roughness was estimated according to land use on the fan; the followings values of the Manning coefficient were selected: 0.07 for channels and bare debris, 0.10 for sparse shrubs areas, and 0.14 for dense shrubs and trees.

Two sets of rheological parameters were used in the analysis. The first rheology, named "Aspen Pit 1" in O'Brien and Julien (1988, p. 882), considers a flow with high values of viscosity and yield strength. The second scenario assumes the "Kang and Zhang" rheology (in O'Brien and Julien, 1988 , p. 882-883), which represents a flow with a mediumlow shear stress. The "Kang and Zhang" rheology proved to produce reliable flooded areas for debris flows generated from dolomite rocks, whose characteristics are similar to those of the debris flows in the studied area (D'Agostino

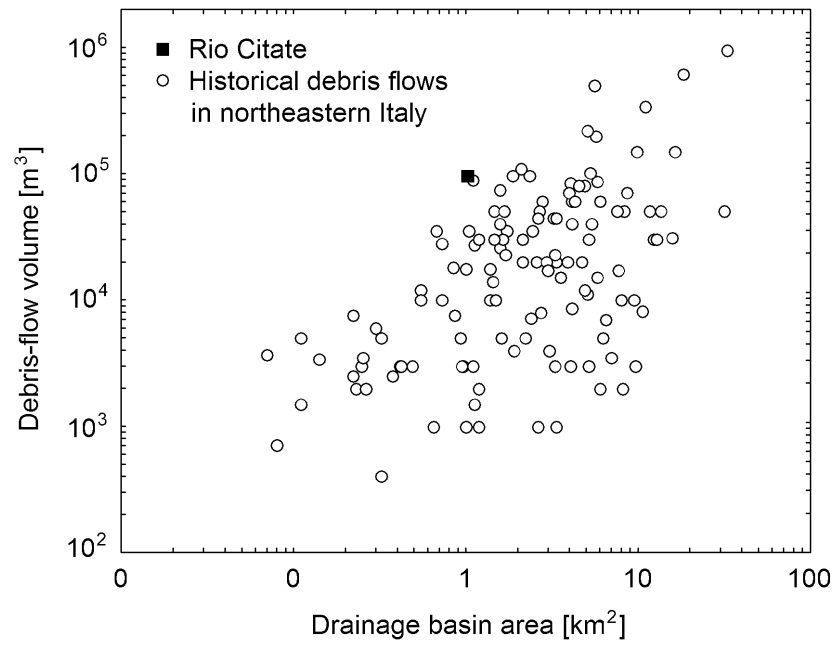

Fig. 9. Comparison of the debris flow of the Rio Citate used for model simulation with a sample of debris-flow volumes recorded in the eastern Italian Alps (modified from Marchi and D'Agostino, 2004).

and Tecca, 2006). Maximum values of flow depths (Fig. 10a) and mean flow velocities along the channel - just upstream of fan apex - are equal to $1.8-2.2 \mathrm{~m}$ and $4.0-4.2 \mathrm{~m} / \mathrm{s}$, respectively. Such values match well with the channel size and the capability of the diverting dike to bear the related maximum pressures.

The results of both simulations demonstrate that the flooded fan area $\left(0.19 \mathrm{~km}^{2}\right.$ with Aspen Pit 1 rheology, and $0.34 \mathrm{~km}^{2}$ with Kang and Zhang rheology) does not involve the southern part of the alluvial fan. Figure 10a presents the map of maximum flow depths for the Kang and Zhang rheology, which computes the largest flooded area. It is possible to note that the longitudinal dike contains the maximum flow depth, and no avulsion occurs to the left banks. The decisive role of the diverting dike on the left bank in preventing the flooding of the southern sector of the alluvial fan is confirmed by model simulation of the same debris flow (Kang and Zhang rheology) after removing the dike (Fig. 10b). The channel reach where maximum flow depths occur shortens (Fig. 10b), but maximum depths do not change (Fig. 10a and b). Maximum flow velocities are reduced by $10 \%$. Total flooded area rises to $0.6 \mathrm{~km}^{2}$, and the absence of the diversion dike causes large areas of the southern sector of the alluvial fan to be inundated, although generally with shallow flow depth. It is also possible to observe that the flooded areas in Fig. 10b agree well with the active areas of the historical map by Gortani (1912) presented in Fig. 5: this supports the choice of the Kang and Zhang rheology in the simulation of the debris flows of the Rio Citate. 

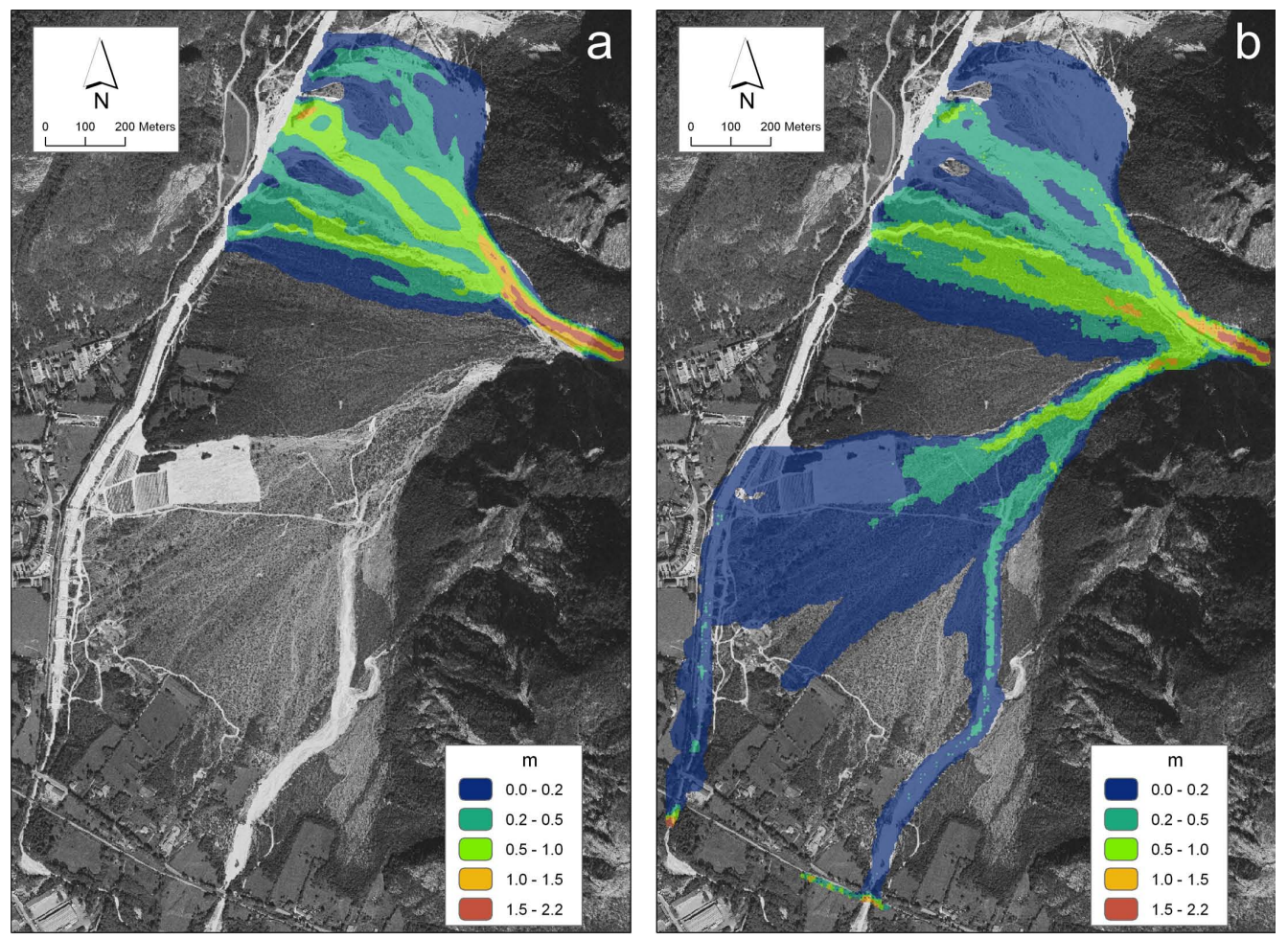

Fig. 10. Application of the FLO-2D model: map of the maximum flow depths. (a) Actual topography, including the presence of the diverting dike on the left bank of the channel. (b) Simulation without the diverting dike.

\section{Discussion}

The lack of major damage from floods and debris flows in recent decades, as well as the development of vegetation in previously bare areas and the narrowing of the channels in the southern part of the alluvial fan (Figs. 5 and 6) could be ascribed to a variety of causes: the depletion of sediment sources within the drainage basins, rainfall conditions less favourable to flood and debris flow occurrence, and the effect of the control works.

Field observations and aerial photo interpretation show that the availability of mobilisable debris in the drainage basin of the Rio Citate, which dominates the Rivoli Bianchi alluvial fan, is not a limiting factor for the occurrence of debris flows.

The analysis of intense precipitation presented in the Sect. 4.1 is not fully exhaustive because also rainstorms that do not correspond to annual maxima may trigger debris flows. However, the absence of a significant decreasing trend in the most intense rainfall for a wide range of durations, including the shortest ones, which are usually associated to debris-flow triggering in the region under study, suggests that the observed decrease in debris-flow activity could hardly be referred to an attenuation of intense rainfall. The decrease of rainfall amounts for the durations from 3 to 5 days could be responsible for an attenuation of long-lasting floods with sediment transport and could repre- sent a possible concomitant cause, but not the only explanation, for the lack of major hydrogeomorphic events in recent decades.

Control works influence the hydrogeomorphic processes on the alluvial fan both through the decrease of sediment transfer from the drainage basin to the alluvial fan, achieved through the use of check dams on the Rio Citate, and the diversion of the channel of the Rio Citate toward the northern sector of the alluvial fan. Although it is difficult to discriminate the relative importance of the two effects, we note that grade control structures built in the basin of the Rio Citate do not prevent the flooding of the northern sector of the fan. The diverting dike thus seems to have played a key role in stabilising the southern sector of the fan, by disconnecting that area from the sediment transport events of the Rio $\mathrm{Ci}$ tate. This is indicated by the expansion of vegetation onto areas formerly almost bare (Fig. 6) or crossed by multiple active channel (cf. the historical map of Fig. 5). The positive verification which was conducted through the numerical model makes stronger the conclusion (Fig. 10). Nevertheless a cautionary note is appropriate: the soundness of a specific application has not to legitimate the dogmatic use of this mathematical tool to assess debris-flow hazard. Actually, a number of physical processes (self-formation of levees, bank and bed erosion, flow-state-dependent rheology, multi-phase flow) are not considered by the model, whose results should be treated with caution. 
The reduction of hazard achieved by torrent control structures, often leads to political pressures to remove land use limitations. This happens also in the Rivoli Bianchi alluvial fan, where the stabilisation of the fan surface occurring in recent decades has resulted in an increased pressure for its economic exploitation (farming and cattle-breeding). When considering these requests, the original objective of torrent control works should be taken into account. With regard to the case study in this paper, the training works on the Rivoli Bianchi alluvial fan were intended to protect the road and the railway located at the southern end of the fan, rather than to achieve a complete stabilisation of the fan surface. These aspects are particularly relevant when the requests for land use changes do not relate to the use of alluvial fans for agriculture, as for the Rivoli Bianchi alluvial fan, but the expansion of urban areas, as often occurs in other alpine areas.

\section{Conclusions}

This study has demonstrated the suitability of a comprehensive approach, based on analysis of historical documents, aerial photo interpretation, field observations and numerical modelling of debris flows, for enabling recognition of contemporary hydrogeomorphic processes and evaluation of the long-term effect of torrent control works on alluvial fans.

Although geomorphic processes causing sediment supply from basin slopes to the channels are still active, and there are no evidences of a reduction in intensity of rainstorms, no debris flows with relevant damage have been recorded in the last decades. The absence of hazardous events since the late 1930s, which differs from repeated debris-flow damage observed in the previous decades (Table 1), can thus be ascribed to the effectiveness of control works implemented on the Rivoli Bianchi alluvial fan. The results of the 2-D numerical simulation of a high-magnitude debris flow, carried out taking into account the control works built on the fan, confirm that flow propagation does not affect areas with elements at risk. Current management considerations of the Rivoli Bianchi alluvial fan are listed below:

- although control structures have produced a reduction of hazards, high-magnitude debris flows can still deposit considerable amounts of debris on the alluvial fan;

- in order to keep the torrent control structures effective, they must undergo periodical maintenance;

- the pressures for permitting cattle breeding on the alluvial fan raise concerns for the stability of a fragile environment and the possible risk of groundwater pollution.

These issues and the associated implications are common to many alluvial fans in alpine valleys, in which the decrease of frequency and severity of debris flows, achieved thanks to hydraulic works, leads to disregard the persistency of residual hazards. The maintenance of torrent control works built in past decades is of major importance to ensure their effectiveness in controlling hazards on alluvial fans. The long time elapsed from early extensive implementation of torrent regulation works in the Alps has urged studies aimed at evaluating their efficiency, and possible need for maintenance (Garitte and Lahousse, 2002; Mazzorana, 2008). In the Rivoli Bianchi area, the check dams of the Rio Cornons and those built on the left sector of the alluvial fan recently underwent maintenance works.

Acknowledgements. This research is partially funded by the European Commission (Sixth Framework Programme, HYDRATE Project, Contract No. GOCE-037024) and PRIN 2007 Project - Italian Ministry MIUR, Dept. TeSAF. The authors wish to thank Simona Scarsini of the Servizio gestione territorio rurale ed irrigazione of Friuli Venezia Giulia Region for providing the geographical data of the study area, and Lucy Clarke for revising an earlier version of the English text. The comments of two reviewers (Marcel Hürlimann and Brian McArdell) have permitted to improve the paper.

Edited by: J. M. Vilaplana

Reviewed by: M. Hürlimann and B. W. McArdell

\section{References}

Aulitzky, H.: Vorläufige Wildbach-Gefährlichkeits-Klassifikation für Schwemmkegel, Österreichische Wasserwirtschaft, 24, 1-3, 1972 (in German).

Aulitzky, H.: Preliminary two-fold classification of torrents, Mitteilungen der Forstlichen Bundesversuchsanstalt, 144, 243-256, 1982.

Aulitzky, H.: Hazard mapping and zoning in Austria: methods and legal implications, Mt. Res. Dev., 14(4), 307-313, 1994.

Barnikel, F.: The value of historical documents for hazard zone mapping, Nat. Hazards Earth Syst. Sci., 4, 599-613, 2004, http://www.nat-hazards-earth-syst-sci.net/4/599/2004/.

Baumann, F. and Kaiser, K. F.: The Muletta debris fan, eastern Swiss Alps: A 500-year debris flow chronology, Arct. Antarct. Alp. Res., 31(2), 128-134, 1999.

Bollschweiler, M. and Stoffel, M.: Debris flows on forested cones reconstruction and comparison of frequencies in two catchments in Val Ferret, Switzerland, Nat. Hazards Earth Syst. Sci., 7, $207-$ 218, 2007, http://www.nat-hazards-earth-syst-sci.net/7/207/2007/.

Boschi, E., Guidoboni, E., Ferrari, G., Mariotti, D., Valensise, G., and Gasperini, P.: Catalogue of strong Italian earthquakes from 461 B.C. to 1997, Version 3 of the Catalogo dei forti terremoti in Italia, Ann. Geofis., 43(4), 609-868, 2000.

Bonicelli, G.: La sistemazione dei "Rivoli Bianchi” di Tolmezzo, Annali dei Lavori Pubblici, 66, 23-32, 1928 (in Italian).

Bovis, M. J. and Jakob, M.: The role of debris supply conditions in predicting debris flow activity, Earth Surf. Proc. Land., 24(11), 1039-1054, 1999.

Brochot, S., Marchi, L., and Lang, M.: L'estimation des volumes des laves torrentielles: méthodes disponibles et application au torrent du Poucet (Savoie), B. Eng. Geol. Environ., 61(4), 389402, 2002 (in French). 
Carulli, G. B. and Slejko, D.: The 1976 Friuli (NE Italy) earthquake, Giornale di Geologia Applicata, 1, 147-156, 2005.

Chow, V. T., Maidment, D. R., and Mays, L. W.: Applied Hydrology - International edition, Mc-Graw-Hill, New York, 572 pp., 1988.

Costa, J. E.: Physical geomorphologhy of debris flow, in: Developments and Applications of Geomorphology, edited by: Costa, J. E. and Fleisher, P. J., Springer-Verlag, Berlin Heidelberg, 268317, 1984.

D'Agostino, V.: Le opere di idraulica torrentizia per il controllo dei sedimenti, Quaderni di Idronomia Montana, 26, 231-250, 2006 (in Italian).

D'Agostino, V. and Marchi, L.: Geomorphological estimation of debris-flow volumes in alpine basins, in: Debris-flow Hazards Mitigation: Mechanics, Prediction, and Assessment, edited by: Rickenmann, D. and Chen, C., Proceedings of the Third International Conference on Debris-flow Hazards Mitigation, Davos, Switzerland, Millpress, Rotterdam, 1097-1106, 10-12 September 2003.

D'Agostino, V. and Tecca, P. R.: Some considerations on the application of the FLO-2D model for debris flow hazard assessment. in: Monitoring, simulation, prevention and remediation of dense and debris flow, edited by: Lorenzini, G., Brebbia, C. A., and Emmanouloudis, D. E., WIT Transactions on Ecology and the Environment, 90, 159-170, 2006.

De Scally, F. A. and Owens, I. F.: Morphometric controls and geomorphic responses on fans in the Southern Alps, New Zealand, Earth Surf. Proc. Land., 29(3), 311-322, 2004.

Garitte, G. and Lahousse, Ph.: Contribution à l'évaluation de l'aléa torrentiel dans le bassin versant du Riou Chanal (Alpesde-Haute-Provence, France), Géomorphologie: relief, processus, environnement, 8(1), 61-70, 2002 (in French).

Gortani, M.: I Rivoli Bianchi di Tolmezzo, Giornale di Geologia Pratica, 4(1), 37-45 1906 (in Italian).

Gortani, M.: Materiali per lo studio delle forme di accumulamento. Falde di detrito e coni di deiezione nella valle del Tagliamento, Memorie Geografiche, 20, 339-433, 1912 (in Italian).

Gortani, M.: Il terremoto del 27 marzo 1928 nelle Prealpi dell' Arzino (Friuli), L'universo, 9(12), 1155-1210, 1928 (in Italian).

Govi, M.: Photo-interpretation and mapping of the landslides triggered by the Friuli earthquake (1976), Bulletin of the International Association of Engineering Geology, 15, 67-72, 1977.

Govi, M. and Sorzana, P. F.: Effetti Geologici del Terremoto: frane, in: Studio Geologico dell' area maggiormente colpita dal terremoto friulano del 1976, edited by: Martinis, B., Rivista Italiana di Paleontologia e Stratigrafia, 83(2), 329-368, 1977 (in Italian).

Guzzetti, F., Cardinali, M., and Reichenbach, P.: The AVI Project: A bibliographical and archive inventory of landslides and floods in Italy, Environ. Manage., 18(4), 623-633, 1994.

Helsen, M. M., Koop, P. J. M., and Van Steijn, H.: Magnitudefrequency relationship for debris flows on the fan of the Chalance torrent, Valgaudemar (French Alps), Earth Surf. Proc. Land., 27(12), 1299-1307, 2002.

Hipel, K. W. and McLeod, A. I.: Time series modelling of water resources and environmental systems, Elsevier, Amsterdam, 1013 pp., 1994.

Hungr, O., Morgan, G. C., Van Dine, D. F., and Lister, R. D.: Debris flow defenses in British Columbia, in: Debris Flows/Avalanches:
Process, Recognition, and Mitigation, edited by: Costa, J. E. and Wieczorek, G. F., Geological Society of America, Reviews in Engineering Geology, 7, 201-222, 1987.

Jackson, L. E., Kostaschuck, R. A., and MacDonald, G. M.: Identification of debris flow hazard on alluvial fans in the Canadian Rocky Mountains, in: Debris Flows/Avalanches: Process, Recognition, and Mitigation, edited by: Costa, J. E. and Wieczorek, G. F., Geological Society of America, Reviews in Engineering Geology, 7, 115-124, 1987.

Ikeya, H.: Debris flow and its countermeasures in Japan, Bulletin of the International Association of Engineering Geology, 40(1), 15-33, 1989.

Liu, K. F. and Huang, M. C.: Numerical simulation of debris flow with application on hazard area mapping, Computat. Geosci., 10(2), 221-240, 2006.

Marchi, L., Pasuto, A., and Tecca, P. R.: Flow processes on alluvial fans in the Eastern Italian Alps, Z. Geomorphol., 37(4), 447-458, 1993.

Marchi, L. and D'Agostino, V.: Estimation of debris-flow magnitude in the Eastern Italian Alps, Earth Surf. Proc. Land., 29(2), 207-220, 2004.

Marchi, L. and Cavalli, M.: Procedures for the Documentation of Historical Debris Flows: Application to the Chieppena Torrent (Italian Alps), Environ. Manage., 40(3), 493-503, 2007.

Mazzorana, B.: Das EF30forward Konzept ein Hinweisinstrument zur Ermittlung der Zuverlässigkeit und Funktionseffizienz von Wasserschutzbauten, in: Interpraevent 2008 Conference Proceedings, Dornbirn-Austria, 1, 415-424, 26-30 May 2008 (in German).

Moscariello, A., Marchi, L., Maraga, F., and Mortara, G.: Alluvial fans in the Italian Alps: sedimentary facies and processes, in: Flood \& Megaflood Processes and Deposits - Recent and Ancient Examples, edited by: Martini, P., Baker, V. R, and Garzon, G., Blackwell Science, Oxford, UK, 141-166, 2002.

O'Brien, J. S. and Julien, P. Y.: Laboratory analysis of mudflows properties, J. Hydraul. Eng.-ASCE, 114(8), 877-887, 1988.

O'Brien, J. S., Julien, P. Y., and Fullerton, W. T.: Two-dimensional water flood and mudflow simulation, J. Hydraul. Eng.-ASCE, 119(2), 244-261, 1993.

Querini, R.: Le lave torrentizie nelle Alpi e Prealpi Carniche e Giulie: nuovi contributi e conoscenze, L'Italia Forestale e Montana, 41(5), 279-300, 1986 (in Italian).

Rickenmann, D., Laigle, D., McArdell, B. W., and Hübl J.: Comparison of 2D debris-flow simulation models with field events, Computat. Geosci., 10(2), 241-264, 2006.

Salmi, T., Maata, A., Antilla, P., Ruoho-Airola, T., and Amnell, T.: Detecting trends of annual values of atmospheric pollutants by the Mann-Kendall test and Sen's slope estimates - the Excel template application MAKESENS, Finnish Meteorological Institute, Publications on Air Quality No. 31, 35 pp., 2002.

Sen, P. K.: Estimates of the regression coefficient based on Kendall's Tau, J. Am. Stat. Assoc., 63, 1379-1389, 1968.

Sosio, R., Crosta, G. B., and Frattini, P.: Field observations, rheological testing and numerical modelling of a debris flow event, Earth Surf. Proc. Land., 32(2), 290-306, 2006.

Stefanini, S.: Le sistemazioni idraulico-forestali nella Carnia (bacino montano del Fiume Tagliamento), Regione Autonoma Friuli - Venezia Giulia, Comunità Montana della Carnia, Tolmezzo, 233 pp., 1982 (in Italian). 
Stefanini, M. C. and Ribolini, A.: Dendrogeomorphological investigations of debris-flow occurrence in the Maritime Alps (northwestern Italy), in: Debris-Flow Hazards Mitigation: Mechanics, Prediction, and Assessment, edited by; Rickenmann, D. and Chen C. (Eds.), Proceedings of the Third International Conference on Debris-flow Hazards Mitigation, Davos, Switzerland, Millpress, Rotterdam, 231-242, 10-12 September 2003.

Stoffel, M.: Magnitude-frequency relationships of debris flows - A case study based on field surveys and tree-ring records, Geomorphology, 116(1-2), 67-76, 2010.
Strunk, H.: Reconstructing debris-flow frequency in the southern Alps back to AD 1500 using dendrogeomorphological analysis, in: Erosion, Debris Flows and Environment in Mountain Regions, edited by: Walling, D. E., Davies, T. R, and Hasholt, B., Proceedings of the Chengdu Symposium, Chengdu, China, IAHS publ. no. 209, 299-306, 5-9 July 1992.

Takahashi, T.: Mechanical characteristics of debris flow,Journal of the Hydraulics Division, ASCE, 104(HY8), 1153-1169, 1978.

Wilford, D. J., Sakals, M. E., Innes, J. L., Sidle, R. C., and Bergerud, W. A.: Recognition of debris flow, debris flood and flood hazard through watershed morphometrics, Landslides, 1(1), 61-66, 2004. 